\title{
Analysis of Accumulated Heavy Metal Concentrations in Various Body Parts of Chillapi (Oreochromis mossambicus) Fish from Ujjani Reservoir of Maharashtra, India
}

\author{
Dnyaneshwar Shinde ${ }^{1}$, Pramod Kamble², D.M. Mahajan'1,Vikas Devkar³, Sanjay Chakane, ${ }^{4, *}$ \\ ${ }^{1}$ Postgraduate Research Center in Environmental Science, Baburaoji Gholap College, India \\ ${ }^{2}$ Department of Environmental Science, Savitribai Phule Pune University, India \\ ${ }^{3}$ Department of Food Science and Post Harvesting Technology, Arts, Science and Commerce College, India \\ ${ }^{4}$ Department of Physics, Arts, Science and Commerce College, India
}

Received September 27, 2019; Revised December 3, 2019; Accepted February 7, 2020

Copyright $\bigcirc 2020$ by authors, all rights reserved. Authors agree that this article remains permanently open access under the terms of the Creative Commons Attribution License 4.0 International License

\begin{abstract}
The heavy metal contamination is creating devastating effects on ecosystem and environment and eventually hazardous to human health. Ujjani is one of the largest reservoir in Maharashtra state. It receives water from different metropolitan cities harboring numerous industries. Moreover, anthropogenic activities pollute water and fish fauna of the reservoir. In the present study, the concentrations of heavy metals such as Iron $(\mathrm{Fe})$, Copper ( $\mathrm{Cu})$, Zinc ( $\mathrm{Zn})$, and Manganese $(\mathrm{Mn})$ were analyzed from various tissues namely muscles, liver, gill, and fin of Chillapi fish. The variation in level of metals was found with respect to tissue types and body weight groups. The concentrations of $\mathrm{Fe}$ were ranged between 15.94 to $91.56 \mu \mathrm{g} / \mathrm{g}, \mathrm{Cu}$ concentration was between 1.88 to $48.88 \mu \mathrm{g} / \mathrm{g}, \mathrm{Zn}$ concentration was between 25.72 to $84.2 \mu \mathrm{g} / \mathrm{g}$ and $\mathrm{Mn}$ was recorded between 2.12 to $28.48 \mu \mathrm{g} / \mathrm{g}$ in Chillapi fish. $\mathrm{Fe}$ and $\mathrm{Cu}$ have recorded highest in the liver, whereas peak of $\mathrm{Zn}$ and $\mathrm{Mn}$ was detected in fins. Furthermore, the minimal metal concentrations were observed in muscle samples of all different weight groups. It shows that $\mathrm{Fe}, \mathrm{Zn}, \mathrm{Cu}$ concentration in all four tissues was within the limit, whereas the Mn level was found to be exceeding the permissible limit as prescribed FAO/WHO, 1989. The presence of heavy metals higher than normal level in fish bodies is a clear indicator of biomagnifications. Furthermore, THQ and HI values were within limit for all studied metals in fish but if consumed in excess amount may cause toxicity in humans. Therefore, daily intake of fish should be strictly monitored to avoid excess intake of these heavy metals. Our study signifies the importance of addressing the heavy metal contamination issue to avoid health related problems.
\end{abstract}

Keywords Ujjani Reservoir, Heavy Metals, Chillapi, Oreochromis mossambicus, AAS, World Health Organization, Biomagnifications

\section{Introduction}

The pollution of fresh water resources is the major concern globally. The discharge of pollutant through anthropogenic activity has been increased tremendously and creating terrible consequences on quality of water [13]. However, the activities like rapid growth of industries, extensive use of fertilizers, pesticides in agriculture and mining has increasing discharge of heavy metals in aquatic environments [4]. Heavy metal contamination leads to devastating effect on the ecosystemand the environment [5, 6]. Heavy metals are predominantly natural trace components of the aquatic environment and also act as micronutrients which are required in limited quantity for growth of living organism, but their level has continuously rising due to anthropogenic activities which is lethal to aquatic environment [7]. Above mentioned sources of pollution alters the physiochemical properties of aquatic habitat, and quality and quantity of fish stocks [7 - 9]. It is well known fact that heavy metals accumulate in the sediment surface, benthic living organisms and these metals exhibit the increasing trend in the concentration through biomagnifications process in the food chain. Fishes are often top choice among all aquatic foods for consumers and frequently susceptible for accumulation of large amount of metals present in water [10]. Presence of organic 
contaminants are less hazardous to the environment because their toxicity reduces with time, but heavy metals cannot be degraded and their concentration increases through bioaccumulation and biomagnifications processes, and they persistent in nature [11].

Fish has rich nutritional value. It contains high proteins, amino acids, vitamins, minerals, and polyunsaturated fatty acids and also an important source of essential heavy metals. Heavy metals like Iron, Copper, Zinc, and Manganese are essential to normal growth as a micronutrient, whereas some other metals such as Arsenic, Cadmium, Mercury and Lead have no role in biological systems and presence of these metals is hazardous to the environment [12-14]. Fish has dietary importance, bioaccumulation of essential as well as nonessential heavy metals in fish leads to a serious adverse effect on a human health [15]. Numerous researchers have reported that heavy metal accumulation results in disturbance in normal cellular activities, oxidative damage to biological macromolecules, DNA and proteins [16]. The prime symptoms of toxicity of metals are intellectual disability in children, dementia, central nervous system disorders, kidney diseases, liver diseases, insomnia, emotional instability, depression and vision disturbance [16, 17]. Moreover, several researchers have studied and found that, metal accumulation also leads to cancer disease [18].

In the present study, the status of fish resources of Ujjani reservoir and its interaction with heavy metals has been studied. Ujjani reservoir is a terminal Reservoir on the river Bhima. It has $14500 \mathrm{Sq}$. km catchment area in the Pune district. In the Western Zone of the Ujjani reservoir, the Bhima river enters and receiving water from the river tributaries such as Mula, Mutha, Ghod, Pawana, Kukadi, Indrayani and Vel. The catchment of the Ujjani reservoir has extreme physiographic and agro-climatic variations. In the last few decades, industrial, urban and agriculture development in the catchment area of the Ujjani reservoir led to the degradation of the water quality. Untreated or inadequately treated sewage, industrial and agriculture waste water generated from Pune and Pimpri Chinchwad urban and rural areas have been directly discharged into Bhima River and its tributaries, and finally it reaches to Ujjani reservoir and creates heavy pollution of reservoir water and aquatic environment [19-20].

Oreochromis mossambicus commonly known as Chillapi is very famous species of the Ujjani reservoir. It shares maximum fish stock in the local and state fish market. Water pollution in the Ujjani reservoir leads to degradation of fish quality. The presence of contaminants in the water habitat leads to bioaccumulation and biomagnifications into fish and finally it enters in food chain. Therefore, this study was targeted to assess the impact of water pollution on Chillapi fish with reference to bioaccumulation and human health hazards of selected heavy metals. Bioaccumulation of heavy metals such as Fe, $\mathrm{Cu}, \mathrm{Zn}$ and $\mathrm{Mn}$ was determined in different tissues like liver, gill and fin of Chillapi fish.

\section{Material and Methodology}

\subsection{Sampling Site Description and Sample Collection}

The study has been performed on the Chillapi fish species of Ujjani reservoir. The Ujjani reservoir (Topo sheet No. 47 N/4; Latitude 180 04' 24" N and Longitude $75007^{\prime} 15^{\prime \prime} \mathrm{E}$ ) is located in the district of Solapur (Taluka Madha). Its catchment area is about $14856 \mathrm{Sq}$. km. This reservoir receives water by several rivers such as Mula, mutha and Bhima. The river Bhima originate from Bhimashankar hills located in Western hills of Maharashtra. Later, these rivers pass through metropolitan and industrialized cities named as Pune, Pimpri Chinchwad and Chakan. Finally, the river water is cached in Ujjani reservoir. Here, we have chosen the sampling locations in between Bhigwan (start point of reservoir) and Bhimanagar (end point of reservoir) villages. The Chillapi fish samples were collected during January 2017 to April 2017, with the help of fishing net and brought to the laboratory. These samples were divided into five categories based on their weight, approximately $150 \mathrm{~g}, 300 \mathrm{~g}, 450 \mathrm{~g}, 600 \mathrm{~g}$, and $750 \mathrm{~g}$. These specimens were dissected to obtain the tissues such as muscle, liver, gill and fin. The whole fish, as well as different dissected tis sues were thoroughly washed with tap water followed by distilled water and excess water was removed by bloating with Whatman filter paper.

\subsection{Sample Preparation for Analysis}

Fish tissues (muscles, liver, gills and fins) of each weight group were weighed $(1 \mathrm{~g})$ and digested with mixture of 10 $\mathrm{ml}$ of concentrated $\mathrm{HNO}_{3} / \mathrm{H}_{2} \mathrm{O}_{2}$ (3:1) on hot plate, initially for 1 hour at room temperature, then for 1 hour at $40^{\circ} \mathrm{C}$ followed by 3 hours at $140^{\circ} \mathrm{C}$. Subsequently, samples were cooled at room temperature. Later, samples were diluted with distilled water to final volume $50 \mathrm{ml}$ and filtered through Whatman paper grade 42 [21, 22], and stored at $4^{\circ} \mathrm{C}$ in the refrigerator for further analysis.

\subsection{Determination of Heavy Metals in Fish Tissue}

The concentrations of $\mathrm{Fe}, \mathrm{Cu}, \mathrm{Zn}$ and $\mathrm{Mn}$ were determined in muscle, liver, gill and fin samples on Atomic Absorption Spectrophotometer (Sistronics, Model AAS 263) by using standard protocols [23].

\subsection{Statistical Analysis}

Data collected were subjected to statistical analysis. Mean, Standard Deviation and Standard Error of the database were calculated. The average values (mean \pm standard error) were compared. 


\subsection{Health Risk Assessment for Fish Consumption}

The values of heavy metal accumulation in fish tissues were used to calculate the estimated daily intake of metals (EDI), target hazard quotients (THQ) and hazard index (HI) separately for adult male and female individuals.

\subsection{Estimated Daily intake of Metals (EDI)}

EDI is measured in ( $\mathrm{mg} / \mathrm{kg}$ body-weight/day) [24].

$$
\mathrm{EDI}=\mathrm{Mc} \times \mathrm{IR} / \mathrm{Bw}
$$

Where, Mc is the metal concentration in the fish muscle $(\mathrm{mg} / \mathrm{kg}$ dry weight). IR is the ingestion rate, which is considered as $19.5 \times 10^{-3} \mathrm{~kg} /$ day $[25,26]$ and this consumption rate was used in health-risk assessment. The hypothesis of an adult ingestion rate of fish over a life time is an assessment of actual fish consumption. BW is an average body weight of Indian male $(57 \mathrm{~kg})$ and female (50 $\mathrm{kg})[27]$.

\subsection{Target Hazard Quotient (THQ)}

To assess the human health risk from consuming the fish contaminated with heavy metals, the target hazard quotient (THQ) was calculated as per USEPA Region III RiskBased Concentration [28]. The THQ is an estimate of the non-carcinogenic risk level rises due to pollutant exposure and calculated by the following equation:

$$
\mathrm{THQ}=\mathrm{Mc} \times \mathrm{IR} \times 10^{-3} \times \mathrm{EF} \times \mathrm{ED} / \mathrm{RfD} \times \mathrm{BW} \times \mathrm{ATn}
$$

Where, THQ is non-carcinogenic risk and is dimensionless. $\mathrm{EF}$ is the exposure frequency (365 days/year). ED is the exposure duration (67 years) (life expectancy of Indian male $=65$ years approximately and for Indian females is 68) years approximately. Therefore, an average of two extremes have been taken. RfD is the reference dose of an individual metal $(\mathrm{mg} / \mathrm{kg} / \mathrm{day})$ [29] (Table 2). ATn is the averaging time for non-carcinogens (365 days/year $\times \mathrm{ED}$ ) [28].

\subsection{Hazard Index (HI)}

To evaluate the overall potential health risk posed by more than one metal, THQ of every metal is summed up and is known as hazard index (HI). The HI can be calculated by the sum of the target hazard quotients of each metal [29].

$$
\mathrm{HI}=\mathrm{THQ} \mathrm{Fe}+\mathrm{THQ} \mathrm{Cu}+\text { THQ Zn + THQ Mn }
$$

\section{Results}

In this study, we have determined concentration of various metals in Chillapi fish tissues in different weight groups by the Atomic Absorption Spectrophotometer (AAS). The observed concentration of different metals in various tissue types and weight groups is shown as bellow in Table 1. Also the values of heavy metal accumulation in fish tis sues were used to calculate the estimated daily intake of metals (EDI), target hazard quotients (THQ) and hazard index (HI) separately for adult male and female individuals (Table 2).

\begin{tabular}{|c|c|c|c|c|c|}
\hline Body weight groups & Tissue types & $\mathrm{Fe}$ & $\mathrm{Cu}$ & $\mathrm{Zn}$ & $\mathrm{Mn}$ \\
\hline \multirow{4}{*}{$\begin{array}{r}150 \mathrm{~g} \\
\pm 10 \mathrm{~g}\end{array}$} & $\mathrm{M}$ & $58.08 \pm 4.53$ & $11.58 \pm 2.77$ & $43.82 \pm 4.79$ & $2.6 \pm 0.41$ \\
\hline & $\mathrm{L}$ & $91.56 \pm 7.28$ & $24.32 \pm 3.58$ & $44.58 \pm 12.18$ & $10.12 \pm 2.72$ \\
\hline & $\mathrm{G}$ & $75.52 \pm 6.52$ & $23.08 \pm 2.49$ & $39.68 \pm 3.66$ & $2.4 \pm 0.59$ \\
\hline & $\mathrm{F}$ & $60.88 \pm 8.30$ & $12.2 \pm 4.79$ & $54.2 \pm 11.42$ & $11.42 \pm 2.65$ \\
\hline \multirow{4}{*}{$\begin{array}{l}300 \mathrm{~g} \\
\pm 10 \mathrm{~g}\end{array}$} & M & $54.22 \pm 3.63$ & $2.64 \pm 0.50$ & $48.06 \pm 2.14$ & $2.12 \pm 0.49$ \\
\hline & $\mathrm{L}$ & $78.03 \pm 9.95$ & $20.88 \pm 7.14$ & $45.98 \pm 13.12$ & $7.22 \pm 2.18$ \\
\hline & $\mathrm{G}$ & $79.98 \pm 2.40$ & $16.9 \pm 5.60$ & $45.46 \pm 3.77$ & $5.98 \pm 2.16$ \\
\hline & $\mathrm{F}$ & $72.18 \pm 7.60$ & $6.48 \pm 2.38$ & $84.2 \pm 9.39$ & $8.52 \pm 2.63$ \\
\hline \multirow{4}{*}{$\begin{array}{l}450 \mathrm{~g} \\
\pm 10 \mathrm{~g}\end{array}$} & $\mathrm{M}$ & $33.86 \pm 6.53$ & $3.76 \pm 0.86$ & $34.74 \pm 3.70$ & $2.16 \pm 0.45$ \\
\hline & $\mathrm{L}$ & $67.64 \pm 15.7$ & $37.68 \pm 9.28$ & $33.44 \pm 0.84$ & $3.66 \pm 0.75$ \\
\hline & $\mathrm{G}$ & $55.6 \pm 11.81$ & $4.7 \pm 0.30$ & $38.74 \pm 3.08$ & $3.58 \pm 0.71$ \\
\hline & $\mathrm{F}$ & $53.4 \pm 5.11$ & $4.524 \pm 0.70$ & $66.28 \pm 3.44$ & $23.28 \pm 3.52$ \\
\hline \multirow{4}{*}{$\begin{array}{l}600 \mathrm{~g} \\
\pm 10 \mathrm{~g}\end{array}$} & $\mathrm{M}$ & $48.66 \pm 4.19$ & $3.76 \pm 0.82$ & $32.04 \pm 2.25$ & $7.46 \pm 2.82$ \\
\hline & $\mathrm{L}$ & $90.56 \pm 23.7$ & $48.88 \pm 8.8$ & $29.16 \pm 2.53$ & $13.3 \pm 1.57$ \\
\hline & $\mathrm{G}$ & $58.38 \pm 3.55$ & $3.76 \pm 0.48$ & $27.88 \pm 3.51$ & $7.52 \pm 1.79$ \\
\hline & $\mathrm{F}$ & $49.54 \pm 5.87$ & $3.7 \pm 0.92$ & $61.24 \pm 3.52$ & $28.48 \pm 5.92$ \\
\hline \multirow{4}{*}{$\begin{array}{l}750 \mathrm{~g} \\
\pm 10 \mathrm{~g}\end{array}$} & $\mathrm{M}$ & $18.7 \pm 5.55$ & $1.88 \pm 0.53$ & $25.72 \pm 3.85$ & $3.42 \pm 0.88$ \\
\hline & $\mathrm{L}$ & $40.26 \pm 5.41$ & $48.76 \pm 14.62$ & $37.8 \pm 7.90$ & $7.88 \pm 1.07$ \\
\hline & $\mathrm{G}$ & $35.52 \pm 2.22$ & $2.2 \pm 0.51$ & $26.22 \pm 4.77$ & $5.1 \pm 1.36$ \\
\hline & $\mathrm{F}$ & $15.94 \pm 5.06$ & $2.08 \pm 0.57$ & $56.60 \pm 17.50$ & $22.66 \pm 5.37$ \\
\hline
\end{tabular}

Table 1. Heavy metal Concentrations ( $\mu \mathrm{g} / \mathrm{g}$ wet weight) in M (muscle), L (liver), G(gill), F (fin) tissue of Chillapi with respect to body weight. Values are Mean \pm S.E., $(\mathrm{n}=5$ for each weight groups) 
Table 2. Estimated daily intake (EDI), Target hazard quotient (THQ) and Hazard index (HI), Reference dose (mg/kg/day) values of metals via consumption of fish Chillapi fish

\begin{tabular}{|c|c|c|c|c|c|c|c|}
\hline \multirow{2}{*}{ Heavy Metals } & \multicolumn{2}{|c|}{ EDI $(\mathrm{mg} / \mathrm{kg}$ body-weight/day) } & \multicolumn{2}{|c|}{ THQ } & \multicolumn{2}{|c|}{ HI } & \multirow{2}{*}{ RfD (mg/kg/day) } \\
\cline { 2 - 5 } & Male & Female & Male & Female & Male & Female & \\
\hline $\mathrm{Fe}$ & 0.019 & 0.022 & 0.027 & 0.031 & & & 0.7 \\
\hline $\mathrm{Cu}$ & 0.004 & 0.005 & 0.12 & 0.13 & \multirow{3}{*}{0.21} & \multirow{2}{*}{0.24} & 0.04 \\
\hline $\mathrm{Zn}$ & 0.014 & 0.017 & 0.049 & 0.056 & & & 0.3 \\
\cline { 1 - 4 } & 0.003 & 0.003 & 0.022 & 0.024 & & & 0.1 \\
\hline
\end{tabular}

\subsection{Iron (Fe)}

The Fe concentrations was observed in the different Chillapi fish tissues in an order such as liver, gill, fin, followed by muscle except $750 \pm 10 \mathrm{~g}$ fish. The highest $\mathrm{Fe}$ level was detected in liver tis sue compared to other tis sue types in all weight groups. The lowest Fe concentration was detected in muscles than other tissue types in all weight groups. A concentration of Fe was highest in $150 \mathrm{~g}$ weight of fish than other weight groups. Overall, it was observed that concentration of $\mathrm{Fe}$ decreases as fish body weight increases (Table 1, Fig. 1.A).

\subsection{Copper $(\mathrm{Cu})$}

As the fish weight rises the accumulation of $\mathrm{Cu}$ in liver showed increasing trend in all weight groups (Table 1, Fig.1.B). Moreover, it was also observed that level of $\mathrm{Cu}$ in muscle, liver, and gill of $150 \mathrm{~g}$ weight group fish was more than all weight groups. Overall, in muscle, gill and fin the $\mathrm{Cu}$ concentration was decreased as fish body weight increased (Table 1, Fig.1.B).

\subsection{Zinc (Zn)}

It was observed that among the all parts of fish tissues $\mathrm{Zn}$ accumulation was highest in fin. Level of $\mathrm{Zn}$ showed descending trend in fish tissue as fin followed by liver, muscle and gill in all weight groups. It was observed that there is less difference in $\mathrm{Zn}$ accumulation among the liver, gill and fin. In case of $300 \mathrm{~g}$ of fish $\mathrm{Zn}$ content was highest than other weight group of fish. Overall, in all tissue types except liver the $\mathrm{Zn}$ showed decreasing trend in concentration as the body weight of fish increases (Table 1 , Fig.1.C).

\subsection{Manganese (Mn)}

In all weight groups of Chillapi fish the accumulation of Mn was highest in fin and lowest in muscle. Furthermore, accumulation of Mn was observed in descending order in tissues as fin, liver, gill and muscle respectively. Accumulation of Mn was seen highest in all tissues of $600 \mathrm{~g}$ weight group of fish than other weight groups (Table 1, Fig.1.D). 

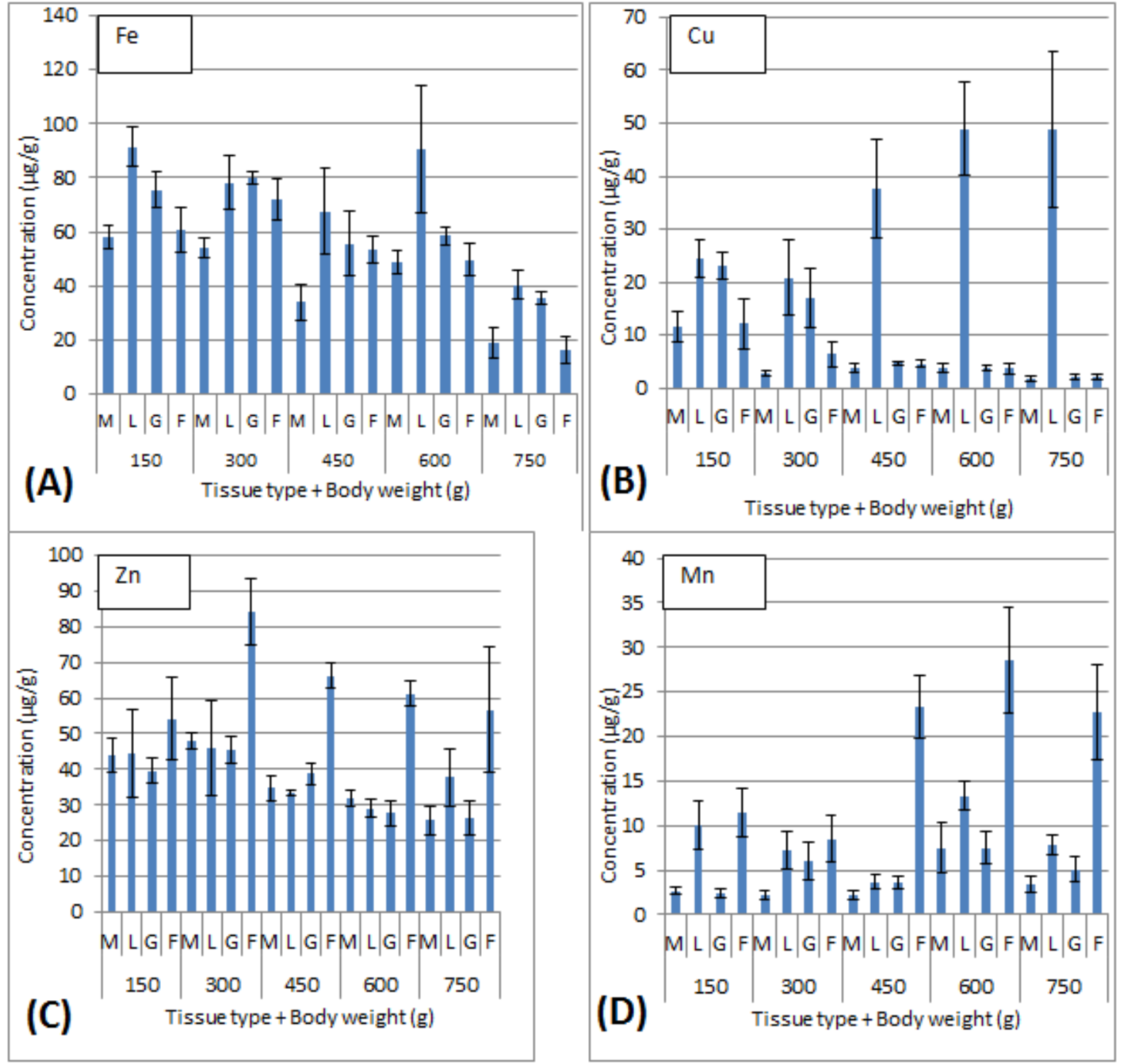

Description: Concentrations of Fe (A), Cu (B), Zn (C) and Mn (D) in M (muscle), L (liver), G(gill) of $150 \pm 10 \mathrm{~g}, 300 \pm 10 \mathrm{~g}, 450 \pm 10 \mathrm{~g}, 600 \pm$ $10 \mathrm{~g}, 750 \pm 10 \mathrm{~g}$ body weight fish. Mean and standard errors are compared (Mean $\pm \mathrm{SE}), \mathrm{n}=5$, concentration in $(\mu \mathrm{g} / \mathrm{g}$ wet weigh t).

Figure 1. The concentration of heavy metals in various body weight groups and tissue types of Chillapi fish

\subsection{Human Health Risk Assessment}

In this study, we have estimated daily intake (EDI), Target hazard quotient (THQ) and Hazard index (HI) values (Table 2). EDI values were lower than the respective reference doses. Among the metals, THQ was highest for $\mathrm{Cu}$ followed by $\mathrm{Zn}>\mathrm{Cu}>\mathrm{Fe}>\mathrm{Mn}$ for both male and female individuals. The values of HI were estimated for both females (0.24) and males (0.21).

\section{Discussion}

In this study, we have investigated metal contents and its distribution pattern in different fish tissues (muscle, liver, gill and fin) with respect to fish body weight. Generally, microelements are beneficial to human being in adequate quantity, while its more abundance in fresh water bodies causes deleterious effects. In general, among the metals, $\mathrm{Fe}$ content is observed to be higher than other metals in fish [30]. The excess intake of Fe through fish food in humans causes symptoms like constipation, nausea, diarrhea, and vomiting. Gastric and esophagealulceration are associated with chronic exposure of $\mathrm{Fe}$ in human beings. Here, in our work, the concentration of $\mathrm{Fe}$ in Chillapi was observed bellow the prescribed standard of FAO/WHO, 1989 (100 PPM) [31]. The decrease in element concentration with increasing body weight was observed in many marine organisms [32]. The study found that heavy metals contamination is higher in well-irrigated agriculture areas [33] and reported fertilizers and heavy metals cause pollution of water bodies and fish.

The Studies carried out on Clarias gariepinus [34], 
Tinca tinca and Selda Tekin [36] reported the highest accumulation of $\mathrm{Fe}$ in the liver and least in muscle. We also observed similar pattern as [34, 35] with respect to $\mathrm{Fe}$ accumulation in liver and muscle. The high concentration of $\mathrm{Fe}$ in the liver may be due to iron-containing enzymes and extensive vascular system, as the hemoglobin interacts with the Fe [36].

To acquire further insight into other metal contents, we determined $\mathrm{Cu}$ level and it was more accumulated in liver. It was noticed that except liver, accumulation of $\mathrm{Cu}$ in other fish parts under study bellow 30 PPM, the limit prescribed by $\mathrm{FAO} / \mathrm{WHO}, 1983$ [37]. Although $\mathrm{Cu}$ is essential, its higher dose can be harmful to human health. Long term exposure to $\mathrm{Cu}$ higher than normal level causes nausea, vomiting, stomach cramps or diarrhea in human beings [38] Researchers also reported the highest $\mathrm{Cu}$ accumulation in the liver of fishes Labeo umbratus [39] Oncorhynchus mykiss, Cyprinus carpio [40]. Even in systemhigh content of $\mathrm{Cu}$ level, fish muscles have poor accumulation properties [41].

It was reported that $\mathrm{Zn}$ accumulation is highest in the liver of Clarias gariepinus [39], Channa punctatus [42] and least in the integument of Channa punctatus [43]. Muscles of Chillapi show the least accumulation of $\mathrm{Zn}$ than other tissues understudy. It is due to the de-loading ability of fish muscles and the transfer of $\mathrm{Zn}$ from muscles to other organs [42, 44]. The accumulation of $\mathrm{Zn}$ in tissues of every weight groups showed below the standard value 100 PPM, permissible limit set by FAO/WHO,1989 [31]. Physiological mechanisms in the body regulate $\mathrm{Zn}$ metabolism in many organisms [45]. Although $\mathrm{Zn}$ is an essential element, high concentration than the permissible limit is hazardous to human beings and other animal health ATSDR, 2005 [44] and causes anemia, damage to pancreas and decrease in the level of high- density lipoprotein (HDL) cholesterol. However, studies on fishes such as Oreochromis mossambicus [46], Tinca tinca [35], Clarias gariepinus [34], reported the highest accumulation in gills than muscles.

The content of Mn observed in all fish tissues under the study was several folds higher than the maximum permissible limits (1 PPM) of Mn set by FAO/WHO, 1989 [31]. Laboratory test with animals has shown that a high level of Mn causes tumor development, abortions, brain damage in animals.

In order to study the risk assessment of heavy metals for human beings by consumption of fish is estimated using several parameters such as estimated daily intake (EDI), target hazard quotient (THQ and hazard index (HI). These parameters are influenced by intake amount of contaminant, exposure frequency and duration, average body weight, and oral reference dose (RfD). THQ is referred as a dimensionless quantity and it is a ratio between concentration of heavy metals in food and RfD. The maximu $\mathrm{m}$ THQ limit value should not exceed 1, otherwise it can cause potential non carcinogenic risks to exposed population. It is also important to note that THQ is not a measure of risk, however it imitates the level of concern $[47,48]$.

In the present study, all four heavy metals showed THQ values less than 1 in all fish samples. Moreover, the THQ values for all concerned heavy metals were comparatively higher in females than males. If the ratio of EDI of heavy metal to its RfD is equal to or less than the RfD then there will be a minimal risk. The ratio obtained for $\mathrm{Fe}, \mathrm{Cu}, \mathrm{Zn}$ and $\mathrm{Mn}$, were less than 1 , indicating that there is no possible health hazard. THQ deals with single heavy metal, but fish accumulates multiple heavy metals, so it becomes essential to calculate hazard index (HI). $\mathrm{HI}$ is the numerical sum of all the THQs. As similar to THQ, HI also should not exceed the limit of $1[49,50]$, if it exceeds the limit then it is an alarming condition for human health. Adult females were found to be more susceptible to heavy metal risks than males [51]. We have observed that $\mathrm{HI}$ values were within the limit for all metals. However, if fish consumption is in excess quantity can cause bioaccumulation and several health hazards to human beings.

\section{Conclusions}

The $\mathrm{Fe}$ and $\mathrm{Cu}$ exhibited more accumulation in liver, whereas $\mathrm{Zn}$ and $\mathrm{Mn}$ showed highest accumulation in fin tissues. Overall, $\mathrm{Fe}, \mathrm{Cu}, \mathrm{Mn}$ and $\mathrm{Zn}$ were accumulated less in the muscle tissue. Among the all metals under study Fe accumulation was highest while $\mathrm{Cu}$ was lowest in all weight groups. In our study, the EDI, THQ and HI values for individual element were lower than 1 , indicating that there was no health risk for consumers due to intake of individual heavy metal through fish consumption. However more daily intake of fish can lead to accumulation of heavy metals and cause deleterious effects.

The effluent released from the urban, industrial and agriculture area contains heavy metals. The discharge of effluent into the river reaches finally to the reservoir and declines the water qualities. Fishes are affected by the accumulation of these metals and concentrate indifferent tissues through the food chain. The high concentration of heavy metals in fish tissues than permissible limits may cause an adverse effect on human health. So, wastewater should be treated before discharged into the water bodies for the safety of aquatic habitat and human health. To avoid epidemics of fishes from such contaminated water, fishes should be screened by food agencies before they reached to the humane. In this study results, indicate that the Ujjani reservoir has a higher pollution load and it was due to the discharge of industrial, agriculture and domestic wastewater which reaches to the reservoir body from its catchment area.

Further studies are suggested particularly to correlate disease patterning in population hosted near the bank on the Ujjani reservoir. Continuous monitoring should be normal 
practice to know the quality of water and fish resources. So we can avoid further negative consequences on the aquatic ecosystemand human health.

\section{Acknowledgements}

The authors wish to acknowledge ITSPM'S, Arts Science and Commerce College, Indapur for research grant and making available all necessary laboratories and instrumentation facilities.

\section{REFERENCES}

[1] Canli M and Kalay OAM. Level of Heavy Metals (Cd, Pb, $\mathrm{Cu}, \mathrm{Cr}$ and $\mathrm{Ni}$ ) in Tissue of Cy prinus carpio, Barbus capito and Chondrostoma regium from the Seyhan River, Turkey. Turkish Journal of Zoology, Vol.22, No.149-157, 1998.

[2] Dirilgen N. Accumulation of heavy metals in freshwater organisms, assessment of toxic interactions. Tur. ChemVol.25, No.173-179, 2001.

[3] Vutukuru S.S. Acute Effects of Hexavalent Chromium on Survival, Oxy gen Consumption, Hematological Parameters and Some Biochemical Profiles of the Indian Major Carp, Labeo rohita. Int. J. Environ. Res. Public Health, Vol. 2, No.456-462, 2005

[4] Noemí R, Verrengia Guerrero, Eva M. Kesten. Levels of heavy metals in biota from the La Plata River. Environmental Toxicology and Water Quality First published by Environmental Toxicology, Vol.8, No.335344, 1993.

[5] Ashraf W. Accumulation of heavy metals in kidney and heart tissues of Epinephelus microdon fish from the Arabian Gulf. Environment Monitoring Assessment, Vol.101 No.311-316, 2005.

[6] Vosyliene MZ, Jankaite EA. The heavy metal model mixture on rainbow trout biological parameters. Ekologika, Vol.4, No. 12 - 17, 2006.

[7] Singh RK, Chavan SL. and Sapkale PH. Heavy metal concentrations in water, sediments and body tissues of red worm (tubifex spp.) collected from natural habitats in Mumbai, India. Environmental Monitoring Assessment, Vol.129, No.471-481, 2006.

[8] Al-Rawi SM. Contribution of manmade activities to the pollution of the Tigris within Mosul area/Iraq. International Journal of Environmental Research \& Public Health, Vol.2, No.245-250, 2005.

[9] Mantovi P, Baldoni G, and Toderi G. Reuse of liquid dewatered and composted sewage sludge on agricultural land: Effects of long-term application on soil and crop. Water Research, Vol.39, No.289 - 296, 2005.

[10] Mansour SA, and Sidky MM. Ecotoxicological Studies. Heavy metals contaminating water and fish from Fayoum Governorate, Egypt. Food Chemistry, Vol.78, No.15-22, 2002.
[11] Aksoy A. Chicory (Cichorium intybus L.): A possible biomonitor of metal pollution. Pakisthan Journal of Botany, Vol.40, No.791 - 797, 2008.

[12] Shallam KHH, El-Sebaey ES, Morshdy AM. Mercury, cadmium and lead levels in Bagrus bayad fish from the River Nile, Delta region, Egy pt. Journal of Egy ptian Public Health Association, Vol.74, No17-26, 1999.

[13] L. Prashanth, K. Kumar K. iRavi T. Chitturi, V. Ramana R. Baddam, L.K. Prasad, A review on role of essential trace elements in health and disease, Journal of Dr. NTR University of Health Science, Vol4, 2, No.75-85, 2015.

[14] Has-Schon E, Bogut, I, Kralik G, Bogut S, Horvatic J, Cacic I. Heavy metal concentration in fish tissues inhabiting waters of "buskoblato" reservoir (Bosnia and Herzegovina). Environmental Monitoring and Assessment, Vol54, No. 75 $-83,2007$.

[15] Tuzen M. Determination of heavy metals in fish samples of the Mid Dam Lake Black Sea (Turkey) by graphite furnace atomic absorption spectrometry. Food Chemistry, Vol.80, No.119-123, 2003.

[16] Flora SJS, Mittal M, Mehta A. Heavy metal induced oxidative stress and its reversal by chelation therapy. Indian Journal of Medical Research, Vol.128, No.501-523, 2008.

[17] Jan AT, Ali A, Haq QMR. Glutathione as an antioxidant in inorganic mercury induced nephrotoxicity. Journal of Postgraduate Medicine, Vol.57, No.72-77, 2011.

[18] Blackadar CB. Historical review of the causes of cancer. World Journal of Clinical Oncology, Vol.6,No.54 -86,2016.

[19] Joshi Sayali \& Joshi Sandeep Eco planning and eco technological solutions for the wastewater from the point and non-point sources of modern urbanization in the Ujjani Reservoir Catchment. 13th World Lake Conference, organized by ILEC \& CSES in Wuhan, China 2009.

[20] Sinha Probir, Joshi Sandeep, Use of Green Bridge and Green Lake Systems to Treat Polluted Streams in Pune City. Proceedings of Workshop on Potential of Eco technology in Water Supply and Sanitation by Shrishti Eco-Research Institute at Pune, No. 33-34, 2007.

[21] Fabunmi Idera, Olumodeji Omotola, Adeleye Adedayo and Uyimadu John Paul, Determination of Heavy Metal Contamination in Lagos Dumpsites Using Earthworms as Bio-indicators. Journal of Scientific Research and Reports, No.81-89, 2015.

[22] Ayse Bahar Yilmaz. Levels of heavy metals (Fe, $\mathrm{Cu}, \mathrm{Ni}, \mathrm{Cr}$, $\mathrm{Pb}$, and $\mathrm{Zn}$ ) in the tissue of Mugil cephalus and Trachurus mediterraneus from Iskenderun Bay, Turkey. Environment Research, Vol. 92, No. 277-281, 2003.

[23] AOAC (Association of official analytical chemists), Official Methods of Analysis, sixteen ed. AOAC Int. Arlington, Virginia. 1995.

[24] Song B, Lei M, Chen T, Zheng YM, Xie YF, Li XY, Gao D. Assessing the health risk of heavy metals in vegetables to the general population in Beijing, China. Journal of Environment Science, Vol. 21, No.1702-1709, 2009.

[25] Little DC, Kundu N, Mukherjee M, Barman BK. Marketing of fish in peri-urban Kolkata. Institute of Aquaculture, University of Stirling, 2002. 
[26] Speedy AW. Global production and consumption of animal source foods. Journal of Nutrition, Vol. 133, No 4048-4053, 2003.

[27] Shukla HC, Gupta PC, Mehta HC, Hebert JR. Descriptive epidemiology of body mass index of an urban adult population in western India. Journal of Epidemiology and Community Health, Vol.56, No. 876-880, 2002.

[28] USEPA (United States Environmental Protection Agency) (2011) USEPA Regional Screening Level (RSL) Summary Table: November 2011.

[29] USEPA (United States Environmental Protection Agency) (2012) EPA Region III Risk-Based Concentration (RBC) Table 2008, Region III, 1650 Arch Street, Philadelphia, Pennsylvania 19103.

[30] Mehjabeen Javed and, Nazura Usmani. Assessment of heavy metal $(\mathrm{Cu}, \mathrm{Ni}, \mathrm{Fe}, \mathrm{Co}, \mathrm{Mn}, \mathrm{Cr}, \mathrm{Zn})$ pollution in effluent dominated rivulet water and their effect on glycogen metabolism and histology of Mastacembelus armatus. Springer Plus, Vol.2, No. 390- 396, 2013.

[31] FAO/WHO National Research Council Recommended Dietary Allowances (10th Eds). National Academy Press, Washington, DC. USA, 1989.

[32] Medina JF, Hernandez A, Pastor JB, Beferull, C Barbera. Determination of $\mathrm{Hg}, \mathrm{Cd}, \mathrm{Cr}$ and $\mathrm{Pb}$ in marine organisms by flameless atomic absorption spectrophotometry. Marine Pollution Bulletin, Vol. 17, No. 41-44, 1986.

[33] ChaisemartinC, Natural adaptation to fertilizers containing heavy metals of healthy and contaminated populations of Austropata mobiuspailpes (LE). Hydrobiology, Vol.17, No.229-240, 1983.

[34] Osman Alaa GM, Werner K. Water quality and heavy metal monitoring in water, sediments, and tissues of the African Catfish Clariasgariepinus (Burchell 1822) from the River Nile, Egypt. Journal of Environment Protection, Vol.1, No.389-400, 2009

[35] SeldaTO, Zan E, Ismail K. Comparative study on the accumulation of heavy metals in different organs of tench (Tincatinca L.1758) and plerocercoids of its endoparasite Ligula intestinalis. Parasitology Research, Vol.97, No156 9, 2005.

[36] Voynar AI, Biologicheskaya Rol'mikroelementov v Organizme Zhivotnykh I Cheloveka Biological Function of Trace elements in Animals and Man). Vyssh, shk. Press, Moscow. 1960

[37] FAO (Food and Agriculture Organization) Compilation of legal limits for hazardous substances in fish and fishery products 1983; FAO Fish Circular 464, No.5-100.

[38] Agency for Toxic Substances and Disease Registry (ATSDR) Agency for toxic substances and disease registry. Division of Toxicology, Clifton Road, Atlanta, 2005.

[39] Coetzee L, du Preez HH, Van Vuren JHJ. Metal concentrations in Clarias gariepinus and Labeo umbratus from the Olifants and Klein Olifants River, Mpumalanga, South Africa: zinc, copper, manganese, lead, chromium, nickel, aluminum and iron. Water SA,Vol.28, No.433-448, 2002.

[40] Boeck G.D, Meeus W, Coen W.D, Blust R. Tissue specific
$\mathrm{Cu}$ bioaccumulation patterns and differences in sensitivity to water borne $\mathrm{Cu}$ in three fresh water fish: rainbow trout (Oncorhyncus mykiss), common carp (Cyprinus carpio), and gibel carp (Carassius auratus). Aquatic Toxicology, Vol.70, No.179-188, 2004.

[41] Stokes PM. Copper accumulations in aquatic biota. in: JO Nriagu (Eds.), Copper in the environment. Part 1 Ecological cycling. Wiley, New York, United States of America, No.358-381, 1989.

[42] Murugan SS, Karuppasamy R, Poongodi K, Puvaneswari S Bioaccumulation Pattern of Zinc in Freshwater Fish Channapunctatus (Bloch.) After Chronic Exposure. Turkish Journal of Fish and Aquatic Science, Vol.8, No. 55-59, 2008.

[43] Javed M, Usmani N. Uptake of Heavy Metals by Channa Punctatus from Sewage-Fed Aquaculture Pond of Panethi, Aligarh. Global Journal of Research in Engineering(C). Vol. 12, No 27-34, 2012.

[44] Madhusudan S, Fatma L, Nadim C. Bioaccumulation of Zn and $\mathrm{Cd}$ in fresh water fishes. Indian Journal of Fishery, Vol.50, No.53-65, 2003.

[45] Eisler R. Zinc hazards to fish, wildlife and invertebrates: A synoptic review. US Fish Wildlife Survey Report Biology, Vol.85, No.1-6, 1988

[46] Robinson J, Avenant- Oldewage A. Chromium, Copper, Iron and Manganese bioaccumulation in some organs and tissues of Oreochromis mossambicus from the lower Olifants River, inside the Kruger National Park. Water S A, Vol.23, No.387.

[47] Harmanescu M, Alda LM, Bordean DM, Gogoasa I, Gergen I. Heavy metals health risk assessment for population via consumption of vegetables grown in old mining area; a case study: Banat County, Romania. Chemistry Central Journal, Vol.5, No.64, 2011.

[48] Khan S, Farooq R, Shahbaz S, Khan MA, Sadique M. Health risk assessment of heavy metals for population via Consumption of vegetables. World Applied Science Journal, Vol. 6, No.1602 -1606, 2009.

[49] Islam MS, Ahmed MK, Al-M amun MH, Islam KN, Ibrahim M, Masunaga S. Arsenic and lead in foods: a potential threat to human health in Bangladesh. Food Abdicative and Contamination Part A, 2014.

[50] Zodape GV. Metal contamination in commercially important prawns and shrimps species collected from Kolaba market of Mumbai (west coast) India. International Journal of Agri Science, Vol.4, No.160-169, 2014.

[51] Vahter M. Berglund M. Akesson A. Liden C. Metals and Women's Health and Environment Research, Vol. 88, No.145-155, 200. 